\title{
Mozart KV 448 Menurunkan Densitas dan Aktivitas Neuroglia Hipokampus Mencit (Mus musculus) Selama Stres Prenatal No. 416-KE
}

\section{Mozart KV 448 decreased densities and activities of hippocampus neuroglia of mice (Mus musculus) during prenatal stress No. 416-KE}

\author{
Shelly Kusumarini R ${ }^{1}$, Lita Rakhma Yustinasari ${ }^{2}$, Eka Pramystha Hestianah ${ }^{2}$, \\ Suryo Kuncorojati ${ }^{2}$, Tutik Juniastuti ${ }^{3}$ \\ ${ }^{1}$ Program Pendidikan Dokter Hewan (PPDH), \\ ${ }^{2}$ Departemen Anatomi Veteriner, \\ ${ }^{3}$ Departemen Kedokteran Dasar Veteriner \\ Fakultas Kedokteran Hewan, Universitas Airlangga \\ Kampus C UNAIR, Jl. Mulyorejo, 60115, \\ Telepon 031-5992785, E-mail: lita.yustinasari@gmail.com
}

\begin{abstract}
The aim of this research was to explore the influence of Mozart KV 448 classical music therapy to the neuroglia cells of mice's hippocampus that were exposed to stress during prenatal. This research were employing twenty female mices and twenty male mices. Female mices were estrus synchronized with PMSG and hCG then monomating to the males. Pregnant females were then divided into four groups (P0, P1, P2, P3). P0 was as control, P1 was treated by one minute forced swim test, P2 was treated by one minute forced swim test followed by thirty minutes classical music Mozart KV 448 and P3 was treated by one minute forced swim test followed by sixty minutes classical music Mozart KV 448. This research was carried out for twenty-one days during gestation period. The neuroglia density result was analyzed using ANOVA and Duncan test. The neuroglia activity result was analyzed using Kruskal wallis test and $\mathrm{Z}$ test. The histology reading showed degradation of density and activity of hippocampus neuroglia.
\end{abstract}

Keywords: prenatal stress, classical music, Mozart KV 448, neuroglia, hippocampus

\begin{abstract}
Abstrak
Tujuan dari penelitian ini adalah untuk mengetahui pengaruh terapi musik klasik Mozart KV 448 pada densitas dan aktivitas dari sel neuroglia hipokampus anak mencit yang terpapar stres selama prenatal. Penelitian ini menggunakan 20 mencit betina dan 20 mencit jantan. Mencit betina kemudian di sinkronisasi estrus dengan PMSG dan hCG setelah itu dilakukan mono mating. Mencit betina yang positif bunting di bagi menjadi empat kelompok (P0, P1, P2, P3). P0 sebagai kontrol tidak diberikan perlakuan apapun, P1 diberikan terapi forced swim test selama satu menit, P2 diberikan terapi forced swim test selama satu menit diikuti musik klasik Mozart KV 448 selama 30 menit dan P3 diberikan terapi forced swim test selama satu menit diikuti musik klasik Mozart KV 448 selama 60 menit. Penelitian ini dilakukan selama 21 hari periode kebuntingan. Analisis data pada densitas neuroglia menggunakan ANOVA dan uji Duncan selanjutnya untuk aktivitas neuroglia data yang diperoleh berupa skor nilai tingkat perubahan aktivitas antar neuroglia sehingga menggunakan uji Kruskal wallis dan uji Z. Hasil gambaran histologi dari penelitian ini menunjukkan penurunan terhadap densitas dan aktivitas neuroglia hipokampus.
\end{abstract}

Kata kunci : stres prenatal, musik klasik, Mozart KV 448, neuroglia, hipokampus 


\section{Pendahuluan}

Stres prenatal merupakan penyakit yang dialami oleh 15-20 \% wanita selama periode kehamilan atau di awal kehamilan (Bennett el al., 2004a,b; Oberlander et al., 2006). Akibat yang ditimbulkan oleh stres prenatal seperti berat badan lahir rendah (BBLR), resiko prematur meningkat dan neonatal abnormality dapat membahayakan kesehatan fetus. Selain itu, stres yang parah juga berhubungan dengan obesitas dan disfungsi metabolik pada keturunan. Peristiwa menegangkan yang dialami ibu juga menambah intensitas stres (Kim et al., 2006). Kondisi stres dapat menghambat perkembangan otak janin hingga menyebabkan perkembangan otak yang lambat (sluggish cognitive tempo) dan Attention Deficit Hyperactive Disorder (ADHD) (Rodriguez and Bohlin, 2005).

StudyNeuropsychologymengenaipaparan musik pada Mus musculus mampu memodulasi perkembangan otak dan neuroplastisitas. Neuroplastisitas dapat terjadi karena rangsangan sensorik dan motorik yang memasuki sistem saraf pusat sehingga terjadi perubahan neuron di otak (Srivastava, 2013; Matthies, 2013). Penelitian yang dilakukan Amagdei et al. (2010) menunjukkan musik dapat mengubah cerebral hemodinamik yang mengaktivasi belahan otak kiri dan kanan. Musik klasik dapat memperbaiki fungsi neuron yang rusak pada bagian basolateral amygdala dan hipotalamus tetapi tidak pada morfologi neuron yang telah rusak (Vina, 2012). Alunan musik klasik Mozart Sonata for two piano D major KV 448 terbukti meningkatkan kapasitas otak dengan mengaktifkan beberapa jalur sinyal pada spasio-temporal (Jau`sovec et al., 2006).

Hubungan stres pada periode prenatal dengan sistem maternal dapat dijelaskan melalui mekanisme Hipotalamus Pituitary Adrenal Axis (HPA-Axis) (Atkinson and Waddell, 1995). Hipotalamus sebagai pusat kendali mekanisme hormon di dalam tubuh akan memproduksi hormon corticotropin releasing factor (CRF); kemudian hipofise anterior akan menghasilkan adrenocorticotropic hormon (ACTH) yang diangkut ke kelenjar adrenal untuk mensekresikan hormon adrenalin. Kelenjar adrenal selain mensekresikan hormon adrenalin juga meningkatkan sekresi glukokortikoid (kortisol), kemudian kortisol tersebut akan memulai serangkaian efek metabolik melalui umpan balik negatif (Tollenaar et al., 2011).

Hipokampus memiliki kepekaan yang tinggi terhadapreseptorglukokortikoid, hal inimenyebabkan hipokampus lebih rentan terhadap kondisi stres dari pada bagian otak lainnya (Rodriguez et al., 2002). Pengaruh yang ditimbulkan oleh glukokortikoid menyebabkan kondisi patologis pada CNS. Neuroglia yang bertugas sebagai modulator neurosekretory neuron akan membantu mempertahankan fungsi neuron melalui proses neurogenesis (Huerta et al., 2010). Stres yang dialami hingga akhir kebuntingan mampu menurunkan ekspresi astrosit reaktif dan mengurangi synaptic density pada frontal cortex, stratum dan hipokampus (Barros et al., 2006).

Penelitian ini bertujuan untuk untuk mengamati pengaruh terapi musik klasik Mozart Sonata KV 448 yang diberikan pada Mus musculus bunting yang mengalami stres prenatal terhadap densitas dan aktivitas neuroglia dari hipokampus anak Mus musculus yang dilahirkan.

\section{Materi dan Metode}

Penelitian ini menggunakan hewan coba mencit (Mus musculus) betina sebanyak 20 ekor umur 3 bulan, sedangkan mencit (Mus musculus) jantan sebanyak 20 ekor umur 4 bulan, untuk dilalukan mono mating. Mencit di adaptasikan dengan kandang dan 
lingkungan dalam laboratorium kandang hewan coba selama empat hari setelah adaptasi kandang selesai pada hari ke lima mencit betina di suntikan hormon PMSG 5 IU 0,1 cc melalui intraperitoneal, kemudian dibiarkan selama 48 jam untuk merangsang proses folikulogenesis. Empat puluh delapan jam setelah penyuntikan PMSG, mencit betina disuntik dengan hCG 5 IU 0,1 cc melalui intraperitoneal, selanjutnya mencit dikawinkan lalu di tunggu hingga muncul vaginal plug yang digunakan sebagai parameter terjadinya mating, pemeriksaan vaginal plug dilakukan lima belas jam setelah penyuntikan hCG.

Perlakuan diawali dengan membagi 20 ekor mencit betina bunting menjadi empat kelompok, yaitu P0 : anak mencit yang lahir dari betina bunting yang tidak mengalami stres prenatal dan tanpa diperdengarkan musik klasik, P1 : Induk bunting yang dibuat stres fisik pada masa kebuntingan dengan berenang satu menit per hari selama kebuntingan 1-20 hari, P2 : Induk bunting yang dibuat stres fisik pada masa kebuntingan dengan berenang satu menit per hari, selanjutnya diterapi musik klasik 30 menit/ hari pada hari ke 1-20, P3 : Induk bunting yang dibuat stres fisik pada masa kebuntingan dengan berenang satu menit per hari, selanjutnya diterapi musik klasik 60 menit/hari. Perlakuan tersebut dilakukan pada hari ke 1-20 kemudian pada hari ke 21 mencit akan melahirkan.

Mencit direnangkan dengan batas waktu satu menit. Setelah itu mencit diberi terapi musik klasik Mozart KV 448 D major yang diperdengarkan pada frekuensi datar20-60 db antara 25-140 kHz dengan jarak efektif $40 \mathrm{~cm}$ (Mustofa, 2013). Hasil Forced Swim test adalah interpretasi dari imobilitas mencit bunting (Airan et al., 2007). Anak mencit yang terlahir dari induk yang diberi perlakuan diambil satu ekor yang memiliki berat badan tertinggi guna memperoleh bagian kepala anak mencit melalui metode cervical dislocation selanjutnya dibuat sediaan histologi. Berat badan tertinggi merupakan parameter terpenuhinya nutrisi fetus di dalam kandungan.

Tahapan pembuatan preparat histologi yang pertama adalah fiksasi. Tahap selanjutnya adalah dehidrasi dan clearing untuk mengeluarkan seluruh cairan yang terdapat dalam jaringan yang telah difiksasi supaya jaringan dapat diisi menggunakan parafin cair kemudian di infiltrasi dan dilakukan pembuatan blok parafin. Proses pengirisan menggunakan mikrotom. Tahapan terakhir adalah pewarnaan menggunakan Haematoxylin Eosin (HE).

Perubahan yang diamati adalah densitas dan aktivitas neuroglia. Pengamatan dilakukan menggunakan mikroskop Olympus ${ }^{\circledR}$ CX-41 dengan perbesaran 400x yang dilengkapi dengan optilab mikroskop digital camera. Pengamatan dilakukan sebanyak lima lapangan pandang berbeda yang masing-masing memiliki luas area $10.000 \mu \mathrm{m}^{2}$ (100 $\mu \mathrm{m}$ kali $100 \mu \mathrm{m})$. Penghitungan pada densitas neuroglia menggunakan software image raster. Aktivitas neuroglia merupakan gambaran aktivitas neuroglia disekitar neuron, apabila neuroglia yang mengelilingi neuron menunjukkan peningkatan (neuroglia sebagai sel penyokong dari neuron) berarti aktivitasnya tinggi (Huerta et al., 2010). Tingkat aktivitas neuroglia dihitung berdasarkan skoring (02). Aktivitas neuroglia dalam susunan normal (0), Aktivitas neuroglia kurang dari 50\% dalam susunan normal (1) dan Aktivitas neuroglia lebih dari 50\% dalam susunan normal (2) (Tiina-Riikka et al., 2001).

\section{Hasil dan Pembahasan}

Rata-rata densitas neuroglia pada P0 adalah $160.3600 \pm 31.54819 ; \mathrm{P} 1$ adalah $137.6800 \pm$ 36.53946; P2 adalah $108.7600 \pm 34.38878$, sedangkan 
P3 adalah $82.0000 \pm 29.55030$. Berdasarkan hasil analisis ANOVA menunjukkan adanya perbedaan yang tidak signifikan diantara perlakuan $(\mathrm{p} 0,01)$, pada P0 $(160.3600 \pm 31.54819)$ memberikan hasil tertinggi terhadap densitas neuroglia yang diikuti dengan P1 (137.6800 \pm 36.53946$)$ dan P2 (108.7600 $\pm 34.38878)$, sedangkan P3 $(82.0000 \pm 29.55030)$ memberikan hasil terendah terhadap densitas neuroglia (Tabel. 1).

Berdasarkan uji lanjut menggunakan Duncan test, $\mathrm{P} 0(160.3600 \pm 31.54819)$ menunjukkan perbedaan yang tidak signifikan dibandingkan dengan P1 (137.6800 \pm 36.53946$),$ P1 (137.6800 \pm 36.53946$)$ menunjukkan perbedaan yang tidak signifikan dengan P2 (108.7600 \pm 34.38878$)$, sedangkan P2 (108.7600 \pm 34.38878) menunjukkan perbedaan yang tidak signifikan dengan $\mathrm{P} 3(82.0000 \pm 29.55030)$.

Tabel 1. Rerata dan simpangan baku perlakuan terhadap densitas neuroglia

\begin{tabular}{cc}
\hline Perlakuan & \pm SD \\
\hline P0 & $160.3600^{\mathrm{c}} \pm 31.54819$ \\
P1 & $137.6800^{\mathrm{bc}} \pm 36.53946$ \\
P2 & $108.7600^{\mathrm{ab}} \pm 34.38878$ \\
P3 & $82.0000^{\mathrm{a}} \pm 29.55030$ \\
\hline
\end{tabular}

a dan b Superskrip dalam satu kolom menunjukkan perbedaan nyata (p 0,01)

Berdasarkan hasil uji analisis dengan Kruskall-Wallis test rata-rata aktivitas neuroglia tertinggi pada P1 adalah 17.50; P2 adalah 13.10; P3 adalah 8.20, sedangkan aktivitas terendah $\mathrm{P} 0 ; 3.20$. Kruskall-Wallis test menunjukkan adanya perbedaan aktivitas neuroglia dari setiap perlakuan, hal ini ditunjukkan dengan nilai p-value sebesar $0,001<$ 0,05, karena itu hipotesis null ditolak. Berdasarkan uji lanjut menggunakan uji $\mathrm{Z}, \mathrm{P} 1^{\mathrm{a}}$ dan $\mathrm{P} 2^{\mathrm{ab}}$ hasilnya menunjukkan tidak signifikan, sedangkan pada $\mathrm{P} 3^{\mathrm{bc}}$ menunjukkan hasil yang signifikan dengan $\mathrm{P} 1^{\mathrm{a}}, \mathrm{P} 2^{\mathrm{ab}}$ dan $\mathrm{PO}^{\mathrm{c}}$ (Tabel. 2).

Tabel 2. Hasil analisis aktivitas neuroglia dengan uji Z

\begin{tabular}{cc}
\hline Perlakuan & Uji Z \\
\hline P0 & $\mathrm{P}^{\mathrm{c}}$ \\
P1 & P1 $^{\mathrm{a}}$ \\
P2 & $\mathrm{P}^{\mathrm{ab}}$ \\
P3 & $\mathrm{P}^{\mathrm{bc}}$ \\
\hline
\end{tabular}

c dan bc Superskrip dalam satu kolom menunjukkan perbedaan nyata $(\mathrm{p} \leq 0,01)$

Neuroglia terlihat bertumpuk-tumpuk dengan persebaran yang rata pada seluruh area hitung (Gambar. 1B), sedangkan gambar 1A tampak berbentuk bulat padat tetapi jarak antar sel cukup renggang sehingga tingkat densitasnya menjadi rendah. Hal ini erat kaitannya dengan konsentrasi kortisol yaitu hormon yang bertanggung jawab untuk merespon kondisi stres yang tinggi dalam SSP, sehingga neurotransmitter akan mensekresikan glutamat, apabila glutamat dalam jumlah berlebih dapat menjadi glutamate excitotoxicity. Aktivasi glutamate-reseptor NMDA akan memobilisasi calcium cytosolic menuju neuron, karena kondisi stres maka konsentrasi calcium cytosolic juga meningkat. Aktivitas dari receptor-glutamat akan menstimulasi ion $\mathrm{Ca}^{2+}$ ke sitoplasma, sehingga jumlah ion $\mathrm{Ca}^{2+}$ berlebihan. Ketidakseimbangan jumlah glutamate excitotoxicity pada kondisi stres dapat memicu kematian sel, hal tersebut dapat menyebabkan penurunan jumlah sel (Lipton, 1999).

Hasil pengamatan terhadap aktivitas antar neuroglia berdasarkan sistem skoring menunjukkan perbedaan nyata. Hal ini tampak neuroglia yang mengelilingi neuron menunjukkan tingkat aktivitas neuroglia tampak tinggi (Gambar 2B). Peningkatan kortisosteron saat stress pada mencit 

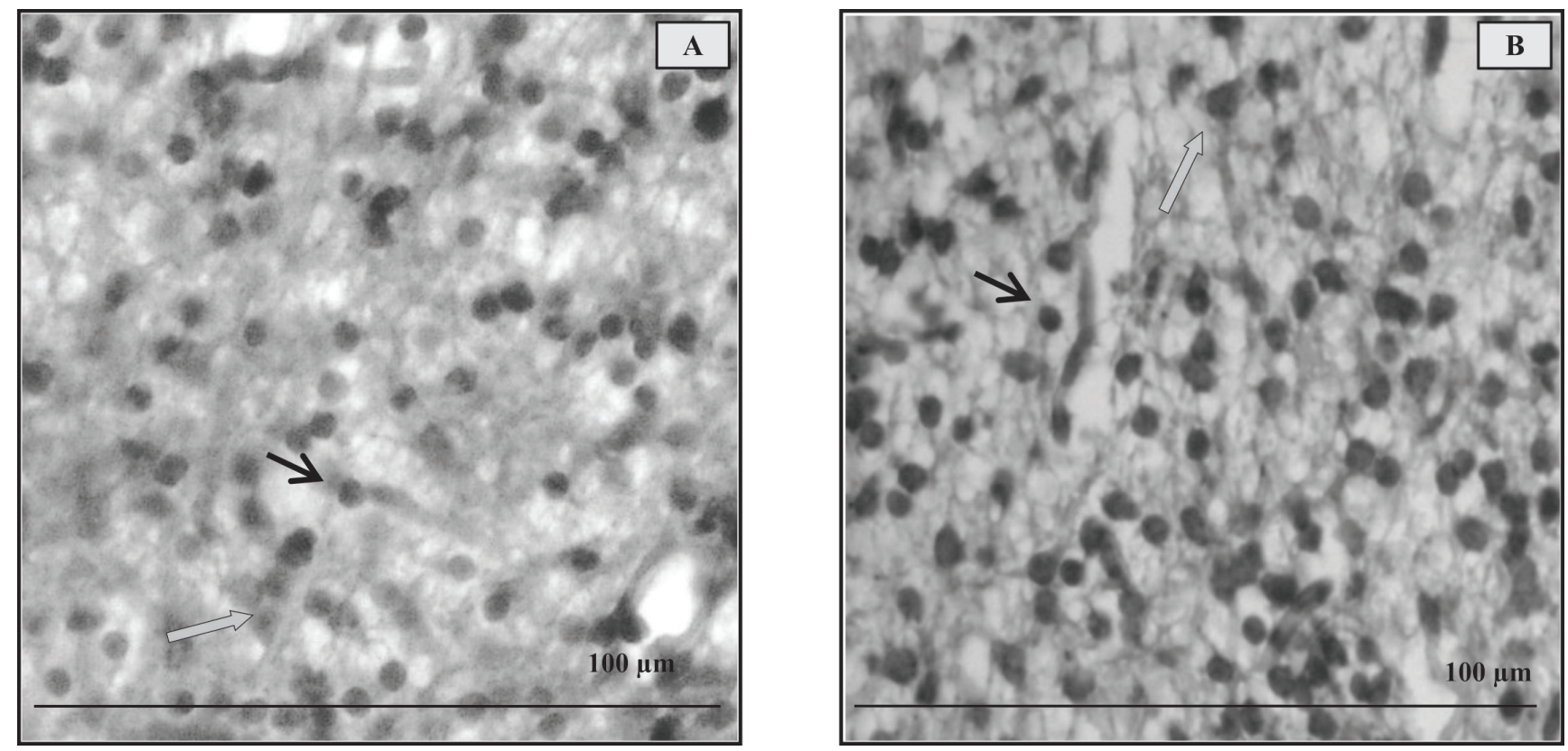

Gambar 1. Irisan axial otak mencit bagian cerebral cortex hipokampus yang menunjukkan densitas neuroglia per $10.000 \mu \mathrm{m}^{2}$. P0 merupakan kontrol sedangkan penurunan densitas neuroglia terjadi pada P3. Pewarnaan Haematoxylin Eosin menggunakan perbesaran 400X dengan Mikroskop Olympus ${ }^{\circledR}$ CX4. Neuroglia $(\rightarrow)$ tampak berwarna lebih gelap dan lebih bulat sedangkan neuron $(\Longrightarrow)$ ukurannya lebih besar menyerupai piramid
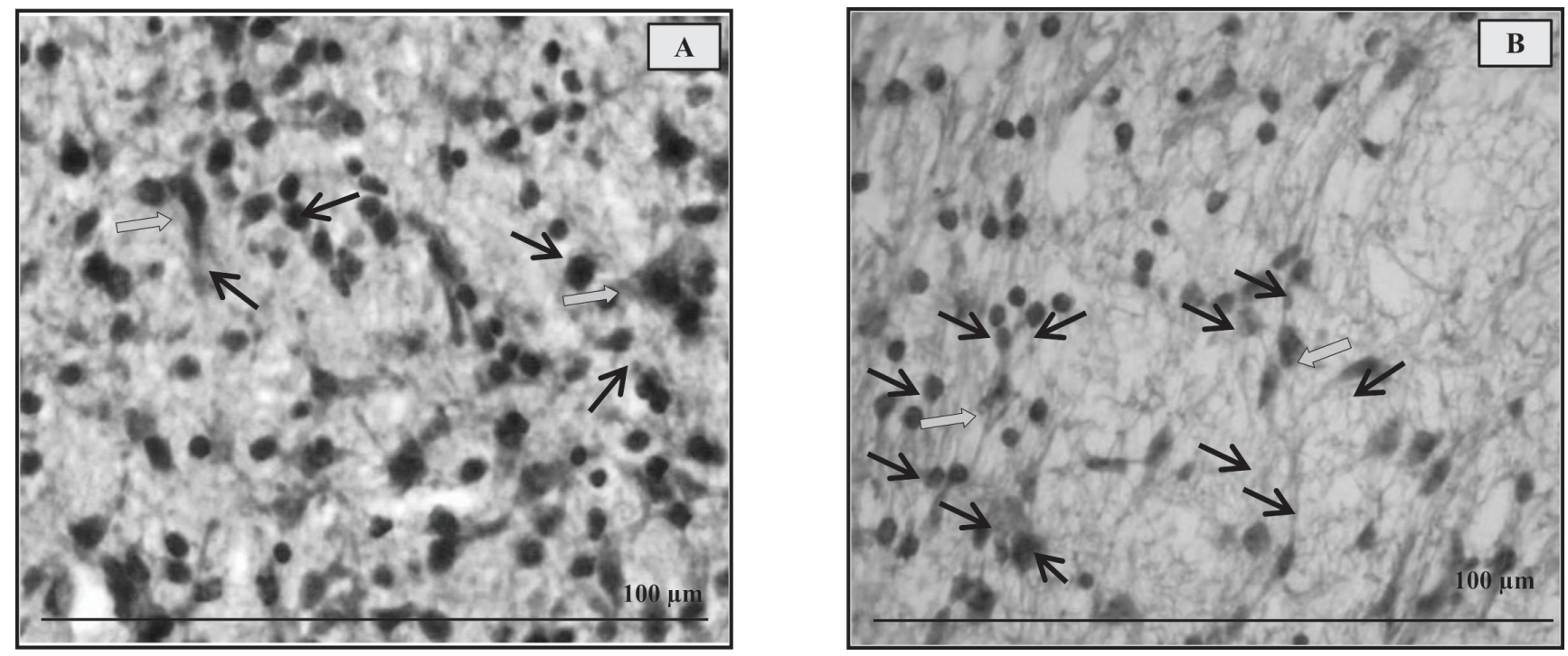

Gambar 2. Irisan axial otak mencit bagian cerebral cortex hipokampus yang menunjukkan aktivitas antara neuroglia. Pewarnaan Haematoxylin Eosin menggunakan perbesaran 400X dengan Mikroskop Olympus ${ }^{\circledR}$ CX-4. Gambar A adalah kontrol dan gambar B adalah kelompok perlakuan.

Keterangan : tanda panah $(\Longrightarrow)$ menunjukkan neuron sedangkan tanda panah $(\rightarrow)$ menunjukkan neuroglia yang mengelilingi neuron.

akan mempengaruhi aktivitas neuroglia terutama astrosit dan mikroglia. Stres yang berjalan dalam waktu lama dapat menyebabkan kerusakan neuron yang mengaktifkan astrosit yang berperan penting dalam fungsi pengaturan synaptogenesis melalui glial transporter uptake dan kemudian mengubahnya 
menjadi glutamin melalui aktivitas enzim glutamin sintetase. Proses ini diharapkan mampu mencegah kerusakan pada neuron (Huerta et al., 2010). Mikroglia akan diaktifkan ketika otak mengalami cidera. Mikroglia akan bermigrasi ke sel target dan menghasilkan proinflamatory molecules, neurotropic factor, dan neurotransmiter untuk membentuk aktivitas synaptik dengan neuron lain, sehingga dapat di ketahui aktivitas antar neuroglia disebabkan oleh aktivitas astosit dan mikroglia yang mempertahankan kondisi normal neuron (Huerta et al., 2010).

Pemberian terapi musik klasik Mozart KV 448 selama periode gestasi terhadap mencit yang mengalami stres prenatal menunjukkan perbedaan yang tidak signifikan $(p \leq 0,01)$ terhadap densitas neuroglia terutama pada kelompok P0 dan P1. Kelompok P2 juga terjadi penurunan densitas neuroglia tetapi penurunan paling signifikan terlihat pada P3. Kelompok P0 sebagai kontrol memiliki tingkat densitas yang tinggi karena proses kebuntingan pada mencit betina akan menyebabkan stres prenatal disamping itu faktor stres dari lingkungan dapat berpengaruh sebab kelompok P0 diletakkan dalam kandang kaca kedap suara dan tertutup sehingga suhu udara meningkat, kondisi ini dipertahankan selama 21 hari. Kondisi lingkungan dapat menjadi faktor pemicu timbulnya stres yang dinilai potensial membahayakan, tidak terkendali atau melebihi kemampuan individu untuk melakukan adaptasi (Lazarus et al., 1985).

Penelitian pendahuluan yang dilakukan untuk mengamati abnormalitas neuroglia pada hipokampus anak yang dilahirkan dari mencit betina bunting yang diterapi dengan forced swim test menunjukkan bahwa abnormalitas neuroglia pada bentuk dan ukuran cukup tinggi, tidak terdapat penjuluran dendrit dan inti sel tidak tampak, sedangkan ukuran neuroglia tidak seragam (Kusumarini dkk., 2016). Kondisi stres akan menyebabkan akumulasi kortikosteron yang dapat mengganggu aktivitas sinaps. Ketika stres terjadi densitas dari neuroglia akan meningkat seiring dengan peningkatan aktivitas neuron mensintesis bioactive molecules dan neurotransmitters yang melewati Gap Junction Communication lalu mengaktifkan astrosit untuk memberikan respon seluler. Jadi apabila neuron mengalami gangguan maka astrosit akan membentuk synaptic plasticity untuk membantu pertahanan neuron (Allen and Barres, 2005).

Paparan musik dengan intensitas yang teratur dapat mencegah efek hipermetabolik yang dicirikan oleh pelepasan beberapa neuroendokrin seperti katekolamin, kortisol, sitokin dan hormon lainnya yang dimodulasi oleh Hipotalamus Pituitary Adrenal Axis (HPA-Axis). Musik merupakan jenis terapi konvensional yang apabila di dengarkan secara konsisten akan memberikan efek rileks dan menurunkan hipermetabolisme dalam SSP, hal tersebut menunjukkan musik klasik mampu menurunkan densitas dari neuroglia (Weissman, 1990).

Berdasarkan uji lanjut menggunakan uji Z, Aktivitas neuroglia pada P1a dan P2ab hasilnya menunjukkan tidak signifikan, sedangkan pada P3bc menunjukkan sangat signifikan dengan P1a, P2ab dan P0c. Musik klasik diyakini oleh banyak orang mampu menurunkan stres khususnya pada kondisi stres prenatal. Efek menyenangkan dan rileksasi diawali dari ditangkapnya gelombang suara oleh telinga kemudian gelombang suara akan ditangkap oleh membran timpani kemudian gelombang suara akan dikonversikan menjadi gerakan mekanis untuk disalurkan menuju koklea. Organ corti yang berada di dalam koklea akan menjalankan fungsinya dengan mengubah getaran mekanik gelombang bunyi menjadi impuls listrik yang akan dihantarkan ke pusat pendengaran (Bilmes, 2005). 
Alunan suara yang dihasilkan oleh musik klasik akan diteruskan pada mesocorticolimbic sehingga berkaitan dengan aktivasi Nucleus Accumbens (NAc) dan Ventral Tegmental Area (VTA). Aktifnya NAc akan mengatur regulasi otonom, emosional, dan fungsi kognitif dalam SSP. Reseptor dopaminergic berasal dari VTA yang diproyeksikan pada daerah NAc dan otak depan. Kondisi rileks tercipta akibat interaksi antara korteks orbito frontal dengan neurotransmitter dopaminerergik (NAc dan VTA). Hipokampus bertanggung jawab terhadap defensif perilaku dalam menanggapi stres dan modulasi hormon kortisol akan memberikan respon terhadap neurotransmitter dopaminerergik, jadi dengan terapi musik klasik terjadi modulasi terhadap hormon kortisol yang menyebabkan kadar stres dalam SSP mengalami penurunan sehingga neurotransmitter dopaminergik akan ditangkap oleh synaptogenesis astrosit dan mikroglia untuk menurunkan aktivitasnya (Brown et al., 2004; Wise, 2004). Jadi dapat disimpulkan bahwa terapi musik klasik Mozart KV 448 terhadap induk mencit (Mus musculus) bunting yang mengalami stres prenatal dapat menurunkan densitas dan aktivitas neuroglia hipokampus anak mencit yang dilahirkan.

\section{Kesimpulan}

Secara umum hasil pemeriksaan gambaran histologi dari penelitian ini menunjukkan bahwa telah terjadi penurunan terhadap densitas dan aktivitas neuroglia hipokampus.

\section{Daftar Pustaka}

Airan, R. D., Meltzer, L. A., Roy, M., Gong. Y., Chen, H, Deisseroth, K. (2007). High-speed imaging reveals neurophysiological links to behavior in an animal model of depression. Science
Magazine. 3 (17): 819-823.

Allen, N. J., and Barres, B. A. (2005). Signaling between glia and neurons: focus on synaptic plasticity. Curr Opion. Neurobiol. 15 (5): 542548.

Amagdei, A., Baltes, F.R., Avram, J., Miu A.C. (2010). Perinatal exposure to music protects spatial memory against callosal lesions. Int $\mathrm{J}$ Dev Neurosci. 28(1): 105-109.

Atkinson, H.C., Waddell, B.J. (1995). The hypothalamic-pituitary-adrenal-axis in rat pregnancy and lactation: circadian variation and interrelationship of plasma adrenocorticotropin and corticosterone. Endocrinology 136: 512-520.

Barros, V.G., Duhalde-Vega, M., Caltana, L., Brusco, A., Antonelli, M.C. (2006). Astrocyte-neuron vulnerability to prenatal stress in adult rat brain. J Neurosci 83: 787-800.

Bennett, H. A., Taddio, A., Koren, G., Einarson, T.R. (2004a). Depression during pregnancy: overview of clinical factors. Clin Drug Investig. 24: 157-179.

Bennett, H.A., Einarson, A..,Taddio, A., Koren, G., Einarson, T.R. (2004b). Prevalence of depression during pregnancy: systematic review. Obstet Gynecol. 103:698-709.

Bilmes, J. (2005). Anatomy and physiology of the ear. Departement of electrical engineering. University of Washington.

Brown, S. (2004). Passive music listening spontaneously engages limbic and paralimbic systems. NeuroReport. 15: 2033-2037.

Huerta, F Jauregui., Delgadillo, Y Ruvalcaba., Gonzalez-Castañeda., Garcia-Estrada J., Perez, O. Gonzalez, and Luquin, S. (2010). Responses of glial cells to stress and glucocorticoids. Curr Immunol. 6(3): 195-204.

Jau`sovec, N., Jau`sovec, K., \& Gerlic, I. (2006). The influence of Mozart's music on brain activity in the process of learning. Clinical Neurophysiology. 117: 2703-2714.

Kim, H., Lee M.H, Chang H.K, Lee T.H, Lee H.H, Shin M.C, et al,. (2006). Influence of prenatal 
noise and music on the spatial memory and neurogenesis in the hippocampus of developing rats. Brain Dev. 28 (2): 109-114.

Kusumarini, Shelly. R., Tutik Juniastuti, Lita Yustinasari. (2016). Musik klasik mozart KV 448 menyebabkan penurunan abnormalitas neuroglia hipokampus mencit (Mus musculus) yang mengalami stres prenatal. Vet Med. 9 (1): 49-54.

Lazarus, R. S., Delongis, A., Folkmann, S., Gruen, R. (1985). Stress and adaption outcomes (The problem of confound measures). American Phycologist. 40(7): 770-790.

Lipton, S. A., Rosenberg, P.A. (1994). Excitatory amino acids as a final common pathway for neurologic disorders, N. Engl. J. Med. 3 (30): 613-622.

Matthies, U., Balog J, Lehmann K. (2013). Temporally coherent visual stimuli boost ocular dominance plasticity. J Neurosci; 33 (29): 11774-11778.

Mustofa, Tika Rhmatillah. (2013). Skrripsi. Pengaruh musik terhadap proliferasi neuron hipokampus mencit (Mus musculus) yang mengalami stres. Universitas Airlangga.

Oberlander, T.F., Warburton, W., Misri, S., Aghajanian, J. Hertzman, C. (2006). Neonatal outcomes after prenatal exposure to selective serotonin reuptake inhibitor antidepressants and maternal depression using populationbased linked health data. Arch Gen Psychiatry. 63:898-906.

Rodriguez, A. Bohlin, G. (2005). Are maternal smoking and stress during pregnancy related to ADHD symptoms in children?. J Child Psychol Psychiatry. 46: 246-254.
Rodriguez, F., Lopeza JC., Vargasa JP., Broglioa C., Gomeza Y., Salas C. (2002). Spatial memory and hippocampal pallium through vertebrate evolution: insights from reptiles and teleost fish. Brain Res. Bull. 57 (3-4): 499-503. PMID 11923018.

Srivastava, D.P., Woolfrey KM, Penzes P. (2013). Insights into rapid modulation of neuroplasticity by brain estrogens. Pharmacol Rev. 65 (4): 1318-1350.

Tiina-Riikka M. Pirttila, Asla Pitkanen, Jarkko Tuunanen, and Risto A. Kauppinen. (2001). Ex vivo mr microimaging of neuronal damage after kainate-induced status epilepticus in rat: correlation with quantitative histology. Magnetic Resonance in Medicine. 46: 946954.

Tollenaar, M.S., Beijers R, Jansen J, Riksen-Walraven JM, de Weerth C. (2011). Maternal prenatal stress and cortisol reactivity to stressors in human infants stress. Stress. 14 (1): 53-65.

Vina, Y. (2012). Skripsi. Pengaruh terapi musik terhadap stres pada Mus musculus dengan induksi food shock. Under graduate Airlangga University. KKB KK-2 FF 357/ 11 Yuw p.

Weissman, C. (1990). The metabolic response to stress: an overview and update. Anaesthesiology. 73: 308-27.

Wise, R.A. (2004). Dopamine, learning and motivation. Nat. Rev. Neurosci. 5: 483-494. 